\title{
Ethnomedicinal plants used for curing various skin diseases in Shopian district of Jammu and Kashmir
}

\author{
Sumer Singh, Khanday Zakir Hussain* \\ Department of Botany, School of life Sciences, Singhania University, Pacheri Bari, Rajasthan, India
}

Received: 05.02.2017

Accepted: 28.02.2017

Published: 05.03.2017

*Address for correspondence:

Khanday Zakir Hussain, School of life Sciences,

Singhania University, Pacheri

Bari, Rajasthan, India.

E-mail.zkhanday@gmail.com

\begin{abstract}
Medicinal plants are commonly used by tribals and local people in Shopian (Jammu and Kashmir) in the treatment of common skin diseases, such as dandruff, hairfall, and dermatitis. Traditional methods of disease treatment using medicinal plant are predominant among rural and tribal communities of Shopian Kashmir. The district Shopian has a rich variety of flora of medicinal plants with tremendous biological properties. Ethnomedicinal survey with respect to the use of local medicinal plants for curing skin problems was carried out during the summer seasons of 2015-2016. The present investigation reveals that 25 ethnomedicinal plants belonging to 21 families are being commonly used in the treatment of a number of skin diseases. An inventory of traditional knowledge about medicinal plants used in skin diseases by local and tribal people as home remedies/folk medicine has been complied (Table 1).
\end{abstract}

KEY WORDS: Diversity, ethnomedicine, Shopian, skin diseases, tribals

\section{INTRODUCTION}

Traditional herbal practitioners play an important role in the health care in developing countries. Global estimates indicate that over $3 / 4^{\text {th }}$ of the 5 billion population of the world cannot afford the products of western pharmaceutical industry and they have to depend upon the use of traditional medicines, which are mainly obtained from plants (Sharma, 2010). This fact is well complied by the WHO in a written list of medicinal plants list of over twenty thousand species. As a part of the planning to reduce financial crises on developing countries which spend some $40-50 \%$ of their total health budget on drugs, WHO currently supports, recommends and helps the inclusion of herbal drugs in national health-care program because such drugs are commonly available with a cheap price within the reach of a common man and as considered to be much safer than the present synthetic drugs (WHO, 2002).

Ethnobotanists and ethnopharmacologists are documenting traditional medical practices and the influence of local remedies in many regions of the world (Mudasir et al, 2009). The central goal of many of these initiatives is to revalidate and promote some old ways of curing and to make people conscious that frequent access to herbal medicines is dependent on the existence of these plants and the ecosystems in which they survive. Validating the efficacy of remedies and returning the results of studies to the people who use them directly is essential.

\section{MATERIAL AND METHODS}

The present ethnomedicinal study has been conducted in several localities of Shopian district of Jammu and Kashmir. It is situated in the south-west of Kashmir division (Raza et al, 1978). The study has been carried out in some villages and far-flung areas of Shopian district. The far-flung areas are inhabited by different ethnic tribes such as Gujjars, Bakerwals, and Paharis which are rich in traditional knowledge (Bhat et al, 2012).

Several field trips were undertaken during the spring and summer seasons of the year 2015-2016, with a view to collect plant of medicinal value and to document the indigenous knowledge (Jain, 1967; Croom, 1983). Information regarding the use of medicinal plants was collected from the local people, hakims and tribal people (Gujjer and Bakerwals). Informants were asked questions in their local language. The information about the use of 
Table 1: Medicinal plants used for various skin diseases in Shopian Kashmir

\begin{tabular}{|c|c|c|c|c|c|c|c|}
\hline S. No. & Botanical name & Family & Local name & Habit & Habitat & Part(s) used & Used for \\
\hline 1 & Aesulus indica Hook & Hippocastanceae & Handoon & Tree & Road sides & Fruit & Cracked heel, dandruff \\
\hline 2 & Allium cepa L. & Lilaceae & Gande & Herb & Cultivated & Bulb & Boil, hairfall \\
\hline 3 & Allium sativum $\mathrm{L}$. & Lilaceae & Rohan & Herb & Cultivated & Cloves & Alopecia areata \\
\hline 4 & Anagalis arvensis L. & Primulaceae & Teherisaban & Herb & Shady moist places & Aerial part & Pimples \\
\hline 5 & Arisaema jacquemontii Blume & Araceae & Haputgogej & Herb & Higher altitudes & Bulb & Skin eruption, boil \\
\hline 6 & Brassica campestris L. & Brassicaceae & Tilgogul & Herb & Cultivated & Seed & Dandruff, hairfall \\
\hline 7 & Borago officinalis L. & Boraginaceae & Botin & Herb & $\begin{array}{l}\text { Dry terrestrial } \\
\text { habitat }\end{array}$ & $\begin{array}{l}\text { Leaves, flowers, } \\
\text { seeds }\end{array}$ & Skin rashes \\
\hline 8 & Colchicum luteum Baker & Lilaceae & Whirkin posh & Herb & Open slopes & Corm & Dandruff \\
\hline 9 & Cuscuta reflexa Roxb. & Cuscutaceae & Kuklipot & Parasitic & $\begin{array}{l}\text { Growing on willow } \\
\text { trees }\end{array}$ & Whole plant & Skin infections, dandruff \\
\hline 10 & Cydonia oblonga Mill. & Rosaceae & Bomb chont & Tree & Cultivated & Fruit, seed & Chopped skin, itching \\
\hline 11 & Datura stramonium L. & Solanaceae & Datur & Herb & Waste places & Seed & Boil \\
\hline 12 & Ficus carica L. & Moraceae & Anjeer & Tree & Cultivated & Fruit & Dermatitis \\
\hline 13 & Juglans regia L. & Juglandaceae & Doon- kul & Tree & Cultivated & Drupe, root & Grey hair \\
\hline 14 & Lycopus europaeus & Lamiaceae & Gagermanz & Herb & Moist places & Aerial part & Skin allergy \\
\hline 15 & Oxalis corniculata L. & Oxalidaceae & Chok-chin & Herb & Cultivated fields & Whole plant, leaves & Skin allergy \\
\hline 16 & Podophyllum hexandrum Royle. & Podophyllaceae & Wan wangun & Herb & Higher altitudes & Rhizome, fruit/leaves & Boil \\
\hline 17 & Ranunculus sceleratus L. & Rananculaceae & Good sochal & Herb & Marshy places & Root & Hypercritic dermatitis \\
\hline 18 & Rheum emodi Wall. Ex. Meissn & Polygonaceae & Pumb-chalan & Herb & Alpine meadow & Rhizome & Boil \\
\hline 19 & Sagittaria sagittifolia L. & Allismaceae & Kew & Herb & Water courses & Leaves & Skin rashes \\
\hline 20 & Saussurea sacra & Asteraceae & Zoogpadshah & Herb & Alpine meadow & Whole plant, root & Pimples, achnes, boil \\
\hline 21 & Thymus serpyllum L. & Lamiaceac & Ardjavind & Herb & Open slopes & Whole plant, flower & Skin rashes \\
\hline 22 & Urtica diocia L. & Urticaceae & Soi & Herb & Waste lands & $\begin{array}{l}\text { Aerial part, leaves, } \\
\text { root }\end{array}$ & Skin infections, dandruff \\
\hline 23 & Vicia faba L. & Fabaceae & Bagle & Herb & Cultivated & Whole plant & Skin abrasions \\
\hline 24 & Vitis vinifera L. & Vitaceae & Dush & Climber & Cultivated & Leaves, fruit & Boil \\
\hline 25 & Xanthium strumarium L. & Asteraceae & Phaghood & Herb & Waste lands & Leaves, root & Boil \\
\hline
\end{tabular}

plants as medicine and folklore were recorded by personal interviews with tribals (Gujjar and Bakerwals), Paharis, shepherds (chopans), and old experienced villagers under study.

\section{RESULTS AND DISCUSSION}

During the ethnomedicinal survey of different inaccessible areas, in Shopian (Jammu and Kashmir), the author found that the local knowledge on medicinal plants abounds and their use is an important link between the dwelling communities and the biodiversity of the district. The use of effective medicinal plant species is, thus strength within this link. However, these plants cannot meet all the health needs but have been confidently used as home remedies. In the present review, 25 species of plants from 21 families have been recorded which are being potentially exploited by the people of Shopian (Jammu and Kashmir) for various skin diseases. The study shows that among the skin diseases, boil, hair fall, allergy, and dermatitis are the major diseases in the villages and far-flung areas of district Shopian of Jammu and Kashmir. The present paper is a brief account of the value of different ethnomedicinal plants used against the diseases by the villagers and tribals of Shopian district of Jammu and Kashmir.

\section{ACKNOWLEDGMENT}

The author is highly thankful to all the authors and researchers who shared their valuable information which was of immense use to prepare this brief review.

\section{REFERENCES}

BhatTA, Nigam G, Majaz M. Study of some medicinal plants of Shopian district, Kashmir (India) with emphasis on their traditional use by Gujjar and Bakerwal tribes. Asian J Pharm Clin Res 2012;5(2):94-8.

Croom EM. Documenting and evaluating herbal remedies. Econ Bot 1983;37:13-27.

Jain SK. Ethnobotany: Its scope and study. Indian Mus Bull 1967;2:39-43.

Raza MA, Mohammad A. The Valley of Kashmir a Geographical Interpretations. Vol. 1. New Delhi: The Land Vikas Publishing House Ltd.; 1978.

Sharma AB. Global Medicinal Plants Demand May touch \$ 5 Trillion by 2050. Indian Express; 2004.

Tantray MA, Tariq KA, Mir MM, Bhat MA, Shawl AS. Ethno medicinal survey of Kashmir ( $\mathrm{J}$ \& K), India. Asian J Tradit Med 2009;4:1-6.

WHO. World Health Organization Traditional Medicine Strategy: 2002-2005. Geneva:WHO; 2002. p. 11. 